\title{
PENGARUH PEMBERIAN TERAPI MUSIK TERHADAP KECEMASAN PASIEN PRE GENERAL ANESTESI DI RS PKU MUHAMMADIYAH YOGYAKARTA
}

\author{
Ichtiarfi Waryanuarita, Induniasih, Yustiana Olfah \\ Jurusan Keperawatan Poltekkes Kemeneks Yogyakarata \\ ·ichtiarfi15@gmail.com \\ o_indiniasih@yahoo.com \\ yustianajogja@gmail.com
}

\begin{abstract}
Pre operative anxiety occur in patients that undergoing anesthesia procedure and elective surgery. Music therapy is one of distraction technique, because music can reduce physiological pain, stress, and anxiety. Music therapy pushed down sympathy nerve system that reduce body stress respons. Music cause the brain release endorphine, increase dopamine level, and help rise up safety feeling. Find out the effect of music therapy to anxiety in pre general anesthesia patients in PKU Muhammadiyah Yogyakarta Hospital. This study uses a quasy experimental which aims to see the difference in pre anesthesia anxiety before and after given music therapy in intervention and control group. This study uses quasy experimental design here takes group pre test and post test with control sort design. Patients is given pre test and post test with APAIS scale, in intervention group with treatment. Samples in this study amounted to 20 respondents of control group and 20 respondents of intervension group. Data collection is done on May to June 2017. The result of collected data were processed using Wilcoxon test with significant $\alpha=0,05$. There is a difference of anxiety before and after in the intervention group using music therapy. Wilcoxon test results obtained Sig. 0,000 $(<0.05)$ so that H1 is accepted or rejected H0. There is a significant effect of music therapy to anxiety on pre general anesthesia patients in PKU Muhammadiyah Yogyakarta Hospital.
\end{abstract}

Keywords : Anxiety, music therapy, and pre general anesthesia.

\begin{abstract}
Abstrak
Kecemasan pre operatif terjadi pada pasien yang akan menjalani prosedur pembiusan dan pembedahan elektif. Terapi musik salah satu teknik distraksi, karena dapat menurunkan nyeri fisiologis, stres, dan kecemasan. Terapi musik menekan sistem saraf simpatik yang terlibat dengan penurunan respon stres tubuh. Musik memicu otak melepaskan endorfin, meningkatkan kadar dopamin, dan membantu meningkatkan rasa kesejahteraan. Tujuan penelitian ini diketahuinya pengaruh pemberian terapi musik pada pasien pre general anestesi di Rumah Sakit PKU Muhammadiyah Yogyakarta. Penelitian ini menggunakan quasi eksperimental yang bertujuan untuk mengetahui perbedaan tingkat kecemasan pasien pre general anestesi sebelum dan sesudah pemberian terapi musik pada kelompok intervensi dan kelompok kontrol. Penelitian ini menggunakan Desain Quasi eksperimental pada penelitian ini mengambil jenis group pre test and post test with control. Pasien diberikan pretest dan posttest menggunakan skala ukur APAIS, pada kelompok perlakuan dilakukan treatment. Sampel pada penelitian ini berjumlah 20 responden kelompok intervensi dan 20 responden kelompok kontrol. Pengumpulan data pada bulan Mei sampai bulan Juni 2017. Hasil pengumpulan data diolah menggunakan uji Wilcoxon dengan signifikan $\alpha=0,05$. ada perbedaan kecemasan sebelum dan sesudah pada kelompok intervensi yaitu dengan terapi musik. Hasil uji Wilcoxon didapatkan Sig. 0,000 $(<0,05)$ sehingga H1 diterima atau H0 ditolak. Kesimpulannya, ada pengaruh pemberian terapi musik terhadap kecemasan pada pasien pre general anestesi di RS PKU Muhammadiyah Yogyakarta.
\end{abstract}

Kata kunci : Kecemasan, , pre general anestesi dan terapi musik. 


\section{Pendahuluan}

Operasi atau tindakan pembedahan menjadi stressor tersendiri bagi pasien yang dapat membangkitkan reaksi stress baik secara fisiologis maupun psikologis. Kecemasan pre operatif secara umum terjadi pada pasien yang akan menjalani prosedur pembiusan dan pembedahan elektif (Jawaid., Musthtaq., Mukhtar, and Khan, 2007). Kecemasan yang timbul menjelang tindakan anestesi akan mengganggu jalannya proses operasi. Kecemasan dapat mengakibatkan frekuensi jantung yang dapat berpengaruh pada tekanan darah dan pernafasan pasien. Kecemasan dapat pula mempengaruhi dosis obat anestesi, kenaikan laju metabolisme basal pre anestesi dan meningkatkan kepekaan terhadap rasa sakit, (Masdin, 2010). Terapi musik merupakan salah satu teknik distraksi yang dapat digunakan, karena musik dapat menurunkan nyeri fisiologis, stress, dan kecemasan dengan mengalihkan perhatian seseorang dari nyeri, (Tamsuri, 2007). Terapi musik dapat menekan sistem saraf simpatik yang terlibat dengan penurunan respon stres tubuh. Musik juga memicu otak untuk melepaskan endorfin, meningkatkan kadar dopamin, dan memblokir jalur nyeri, semua yang dapat membantu untuk meningkatkan rasa kesejahteraan, (Lin., Chu., Yang., Chen., and Chen, 2011); (Guetin, 2009).

Studi Pendahuluan di RSUP Soeradji Tirtonegoro didapatkan 8 pasien pre anestesi mengalami kecemasan, 3 diantara 8 pasien mengalami peningkatan tekanan darah, dan diperoleh hasil penelitian bahwa pasien mengalami kecemasan ringan 64,5\%, dan 35,5\% pasien mengalami kecemasan sedang, (Pratiwi, 2009). Sedangkan dari 30 pasien yang akan dilakukan anestesi dan operasi, 4 orang $(13,3 \%)$ menunjukkan tingkat kecemasan sedang, 20 orang $(66,7 \%)$ tingkat kecemasan ringan, dan 6 orang $(20 \%)$ sama sekali tidak mengalami kecemasan, (Nurmala, 2009).

Data dari RS PKU Muhammadiyah Yogyakarta menunjukkan bahwa rata-rata per bulan terdapat 118 pasien yang menjalani tindakan operasi dengan general anestesi. Hasil wawancara dengan salah satu perawat kamar operasi RS PKU Muhammadiyah Yogyakarta mengatakan bahwa puncak kecemasan berdasarkan pengamatan oleh perawat bangsal maupun perawat kamar operasi yaitu 2 jam sebelum pasien menjalani operasi di bangsal atau sekitar 30-150 menit pre operasi. Gejala sering tampak pada pasien yang mengalami cemas pre operasi yaitu tampak gelisah, sering menarik napas dalam, nadi dan tekanan darah meningkat $20 \%$ hingga $30 \%$. Tujuan Penelitian adalah mengetahui pengaruh pemberian terapi musik terhadap penurunan tingkat kecemasan pasien pre general anestesi di RS PKU Muhammadiyah Yogyakarta.

\section{Metode Penelitian}

Jenis penelitian yang digunakan adalah penelitian eksperimental semu (quasy eksperimen). Desain yang digunakan adalah jenis "Non-randomized pre test - post test with control group design”.Sampel penelitian yaitu pasien pre general anestesi di RS PKU Muhammadiyah Yogyakarta. Sampel diambil secara purposive sampling dengan krteria inklusi: beruasia 17-55 tahun, bersedia menjadi responden, berstatus fisik ASA I dan II, muslim, dan pasien dapat membaca serta dengan kriteria eksklusi: pasien emergency/ cito responden dan memiliki gangguan pendengaran. Besar sampel sebanyak 40 dengan masing-masing 20 setiap kelompok yang diperoleh dari rumus penghitungan sampel untuk uji hipotesis menggunakan skala ordinal. Data hasil penelitian kemudian diuji dengan analisis Wilcoxon matched pairs.

Penelitian dilakukan di bangsal perawatan sehari sebelum operasi dilaksanakan dilakukan pengkajian pasien. Apabila pasien memenuhi kriteria inklusi dan eksklusi, maka pasien diberikan penjelasan sebelum penelitian (PSP). Peneliti menanyakan musik apa yang disenangi responden dan menjelaskan bahwa responden akan diperdengarkan musik keesokan harinya 2 jam sebelum dibawa ke ruang operasi. Setelah diberikan penjelasan, peneliti/ enumerator mengisi identitas responden kemudian responden akan diminta mengisi pre-test dengan menggunakan kuesioner APAIS. Responden mendengarkan musik yang disukai (musik klasik 
instrumental Yiruma yang berjudul River Flow in You dan Destiny of love dan musik religi nasyid Hafiz Hamidun yang berjudul Allah dan Astaghfirullah) dengan durasi musik klasik instrumental 8 menit 7 detik sedangkan musik religi berdurasi 7 menit 37 detik dengan menggunakan headphone dan MP3 serta menganjurkan responden untuk menikmati musik yang didengarkan. Setelah diberikan terapi musik, pasien diminta mengisi kuesioner post test.

\section{HASIL PENELITIAN}

Karakteristik Responden

Tabel 1. Distribusi Frekuensi Karakteristik Responden

\begin{tabular}{|c|c|c|c|c|}
\hline \multirow[b]{2}{*}{ Karakteristik } & \multicolumn{2}{|c|}{ Intervensi } & \multicolumn{2}{|c|}{ Kontrol } \\
\hline & frekuensi & prosentase & frekuensi & prosentase \\
\hline \multicolumn{5}{|l|}{ 1.Umur } \\
\hline a. $17-25$ tahun & 5 & 25 & 6 & 30 \\
\hline b. $26-35$ tahun & 2 & 10 & 4 & 20 \\
\hline c. $36-45$ tahun & 3 & 15 & 7 & 35 \\
\hline d. 46-55 tahun & 10 & 50 & 3 & 15 \\
\hline \multicolumn{5}{|l|}{ 2.Jenis kelamin } \\
\hline a. Laki-laki & 11 & 55 & 10 & 50 \\
\hline b. Prempuan & 9 & 45 & 10 & 50 \\
\hline \multicolumn{5}{|l|}{ 3. ASA } \\
\hline a. ASA I & 13 & 65 & 17 & 85 \\
\hline b. ASA II & 7 & 35 & 3 & 15 \\
\hline \multicolumn{5}{|l|}{ 4. Pengalaman Operasi } \\
\hline a. Ada & 2 & 10 & 2 & 10 \\
\hline b. Tidak Ada & 18 & 90 & 18 & 90 \\
\hline \multicolumn{5}{|l|}{ 5.Tingkat Pendidikan } \\
\hline a) SD & 0 & 0 & 0 & 0 \\
\hline b) SMP & 2 & 10 & 3 & 15 \\
\hline c) SMA & 16 & 80 & 12 & 60 \\
\hline d) Perguruan Tinggi & 2 & 10 & 5 & 25 \\
\hline Total & 20 & 100 & 20 & 100 \\
\hline
\end{tabular}

Hasil data responden pada tabel 1, rata- rata kelompok intervensi berumur 46-55 tahun 10 orang $(50 \%)$, sebagian besar laki-laki 11 orang $(55 \%)$, sebagian besar responden dengan status fisik ASA I 13 orang (65\%), dan sebagian besar responden berpendidikan SMA yaitu 16 orang $(80 \%)$. Sedangkan pada kelompok kontrol rata-rata berumur 36 - 45 tahun 7 orang (35\%), responden laki-laki 10 orang $(50 \%)$ sama dengan perempuan 10 orang (50\%), sebagian besar responden dengan status fisik ASA I 17 orang (85\%), sebagian besar responden berpendidikan SMA yaitu 12 orang $(60 \%)$.

\section{Tingkat Kecemasan Pasien Pre General Anestesi Sebelum Perlakuan}

Tabel 2. Tingkat kecemasan pasien pre general anestesi sebelum perlakuan

\begin{tabular}{cccccc}
\hline No & \multirow{2}{*}{ Kecemasan } & \multicolumn{2}{c}{ Intervensi } & \multicolumn{2}{c}{ Kontrol } \\
\cline { 3 - 6 } & & frekuensi & prosentase & frekuensi & prosentase \\
\hline 1 & Tidak Cemas & 0 & 0 & 0 & 0 \\
\hline 2 & Cemas Ringan & 5 & 25 & 1 & 5 \\
\hline 3 & Cemas Sedang & 7 & 35 & 11 & 55 \\
\hline 4 & Cemas Berat & 8 & 40 & 8 & 40 \\
\hline 5 & Panik & 0 & 0 & 0 & 0 \\
\hline Jumlah & 20 & 100 & 20 & 100 \\
\hline
\end{tabular}


Hasil pengolahan data tabel 2, didapatkan bahwa mayoritas responden pada kelompok intervensi mengalami cemas berat sebanyak 8 responden (40\%), sedangkan pada kelompok kontrol didapatkan bahwa mayoritas responden mengalami cemas berat sebanyak 11 responden $(55 \%)$.

\section{Tingkat Kecemasan Pasien Pre General Anestesi Setelah Perlakuan}

Tabel 3. Tingkat kecemasan pasien pre general anestesi sebelum perlakuan

\begin{tabular}{clcccc}
\hline \multirow{2}{*}{ No } & \multirow{2}{*}{ Kecemasan } & \multicolumn{2}{c}{ Kelp Intervensi } & \multicolumn{2}{c}{ Kelp Kontrol } \\
\cline { 3 - 6 } & & frekuensi & prosentase & frekuensi & prosentase \\
\hline 1 & Tidak Cemas & 5 & 25 & 0 & 0 \\
2 & Cemas Ringan & 7 & 35 & 5 & 25 \\
\hline 3 & Cemas Sedang & 8 & 40 & 10 & 50 \\
\hline 4 & Cemas Berat & 0 & 0 & 5 & 25 \\
\hline 5 & Panik & 0 & 0 & 0 & 0 \\
\hline Jumlah & 20 & 100 & 20 & 100 \\
\hline
\end{tabular}

\section{Hasil uji bivariat dengan Uji Wilcoxon}

Tabel 4. Uji Wilcoxon Pengaruh Terapi Musik Terhadap Kecemasan Pasien Pre General Anestesi pada Kelompok Intervensi dan Kelompok Kontrol

\begin{tabular}{ccccc}
\hline \multicolumn{2}{c}{ Kelompok } & Mean & $\mathrm{Z}$ & P Value \\
\hline Intervensi & Sebelum & 3,15 & $-4,472$ & 0,000 \\
& Sesudah & 2,15 & & \\
\hline \multirow{2}{*}{ Kontrol } & Sebelum & 3,35 & $-2,646$ & 0,008 \\
& Sesudah & 3,00 & & \\
\hline
\end{tabular}

Berdasarkan tabel 4, menunjukkan hasil uji statistik sampel Wilcoxon didapatkan hasil nilai $p$-value pada uji Wilcoxon lebih kecil dari 0,05 sehingga ada pengaruh yang signifikan antara pemberian terapi musik terhadap penurunan kecemasan pada pasien pre anestesi dengan tindakan general anestesi di Rumah Sakit PKU Muhammadiyah Yogyakarta.

\section{Pembahasan}

Kecemasan pada pasien pre general anestesi

Berasar uji pada tabel 4. memperlihatkan hasil uji wilcoxon didapatkan jika nilai p 0,000 maka nilai $\mathrm{p}<0,05$. Dapat disimpulkan ada perbedaan skor kecemasan sebelum dan sesudah pada kelompok intervensi dan kelompok kontrol pada pasien pre general anestesi di Rumah Sakit PKU Muhammadiyah Yogyakarta. Sebagian manusia yang menunjukkan kecemasan, riwayat hidup dan riwayat keluarga merupakan predisposisi untuk berperilaku cemas, kecemasan sebagai suatu respon terhadap stressor lingkungan, seperti pengalamanpengalaman hidup yang penuh dengan ketegangan, kecemasan dapat dipandang sebagai sesuatu yang dikondisikan oleh ketakutan terhadap rangsangan lingkungan yang spesifik. Responden laki-laki memiliki beban hidup atau stressor yang lebih berat dibandingkan dengan perempuan, sehingga mereka merasa kehilangan beberapa kemampuan sebagai kepala keluarga pada saat terbaring di rumah sakit, (Kaplan., Sadock., dan Grebb, 2010).

Kecemasan yang berlebihan akan menyebabkan pasien tidak tenang dalam menghadapi tindakan, sehingga bisa meningkatkan dosis beberapa jenis obat-obat anestesi yang dipakai, hal ini akan menyebabkan peningkatan pada biaya pasien, adapun beberapa faktor yang mempengaruhi tingkat kecemasan pasien yang akan dilakukan tindakan operasi dan anestesi : faktor genetik, demografi, psikologis, pencetus, perentan, dan faktor pembentuk gejala, (Hawari, 2006). Persiapan mental merupakan hal yang harus dipersiapkan dalam tahap pre operasi karena mental pasien yang tidak siap dapat mempengaruhi kondisi fisik pasien yang akan menjalani tindakan anestesi dan pembedahan. Masalah yang biasa muncul pada pasien 
pre operasi adalah kecemasan. Maka diperlukan langkah pre anestesi yang baik untuk menurunkan kecemasan.

Upaya untuk menurunkan kecemasan pre anestesi dapat dilakukan oleh seorang perawat anestesi pada saat melakukan kunjungan pre anestesi. Ada beberapa cara yang dapat dilakukan untuk menurunkan kecemasan pre anestesi yaitu terapi farmakologis dan non farmakologis (psikologis). Terapi musik merupakan salah satu terapi non farmakologis yang efektif, karena musik dapat menurunkan nyeri fisiologis, stress, dan kecemasan dengan mengalihkan perhatian seseorang dari nyeri (Tamsuri, 2007).

Pasien yang mengalami cemas membutuhkan dukungan psikologis (Djohan, 2009). Mendengarkan musik yang disukai, pasien merasa senang dan nyaman. Pasien mengikuti lagu dan bernyanyi mengikuti irama yang didengarkan menggunakan headphone. Pasien yang ikut bernyanyi akan membawa suasana hati ke dalam lagu atau membawa pasien mengenang kepada suatu keadaan/pengalaman yang menyenangkan. Terapi musik akan mengalihkan perhatian terhadap cemas (distraksi) dan memberikan rasa rileks. Terapi musik juga mempunyai tujuan membentu mengekspresikan perasaan, membantu rehabilitasi fisik, memberi pengaruh positif terhadap kondisi suasana hati dan emosi, meningkatkan memori serta menyediakan kesempatan yang unik untuk berinteraksi dan membangun kedekatan emosional. Dengan demikian, terapi musik juga dapat membentu mengatasi stres dan kekhawatiran seseorang dan meringankan rasa sakit.

Tingkat kecemasan pada pasien pre general anestesi sebelum dan sesudah mendapatkan perlakuan

Hasil penelitian kelompok intervensi digambarkan pada tabel 2, adalah sebelum diberikan perlakuan sebagian besar responden mengalami cemas berat yaitu sebanyak 8 orang $(40 \%)$ dan minimal mengalami cemas ringan. Setelah diberikan terapi musik, responden pada kelompok intervensi tidak ada yang mengalami cemas berat. Setelah diberikan perlakuan, kecemasan responden menurun menjadi cemas sedang, cemas ringan, hingga tidak cemas. Penelitian ini menunjukkan pada kelompok intervensi mengalami penurunan tingkat kecemasan pre general anestesi setelah diberikan terapi musik sesuai keinginan responden (musik instrumental klasik dan musik religi). Penurunan kecemasan yang dialami responden disebabkan karena keberhasilan dari pemberian terapi musik pada pasien pre general anestesi sehingga responden menjadi lebih nyaman dan rileks. Dan pada kelompok kontrol sebelum diberikan perlakuan sebagian responden mengalami cemas sedang yaitu sebanyak 11 orang (55\%), dan cemas berat 8 orang (40\%). Setelah perlakuan (post-test), pada kelompok kontrol didapatkan masih terdapat responden yang mengalami cemas berat atau tidak mengalami penutunan kecemasan. Faradisi (2012) berpendapat bahwa musik dapat menurunkan gejala fisiologi, stress, dan kecemasan. Musik mempengaruhi perubahan fisiologis seperti menurunkan tekanan darah, detak jantung, mengurangi ketegangan otot.

\section{Pengaruh Terapi Musik dalam Menurunkan Kecemasan pada Pasien Pre General anestesi}

Hasil uji Wilcoxon menujukkan perbedaan yang bermakna antara kelompok kontrol dan kelompok intervensi, yaitu $p=0,000(\mathrm{p}<0,05)$. Dalam kolom mean rank kelompok intervensi lebih tinggi $(10,50)$ dibanding kelompok kontrol $(4,00)$. Hal ini berarti kelompok intervensi dengan terapi musik sesuai keinginan responden (musik klasik instrumental dan musik religi) lebih efektif menurunkan kecemasan pre general anestesi dibandingkan dengan kelompok kontrol yang tidak diberi terapi musik. Penelitian ini sesuai dengan penelitian yang dilakukan peneliti sebelumnya yang menyimpulkan terdapat perbedaan signifikan pada tingkat kecemasan pasien sebelum dan sesudah diberikan terapi musik klasik dengan $p=0,000$ ( $\mathrm{p}<$ 0,05)' (Savitri, 2016). Adanya penurunan kecemasan pada pasien setelah diberikan relaksasi dan aromterapi. Hasil uji $t$-test didapatkan nilai t 2,500 dengan nilai sig-nifikansi ( $p$-value) 
0,019. Persamaan dari kedua penelitian tersebut adalah terapi komplementer yang diberikan berhasil menurunkan tingkat kecemasan pasien.

\section{Kesimpulan}

Pemberian terapi musik berpengaruh terhadap kecemasan pasien pre general anestesi. Terapi musik dapat digunakan untuk melengkapi intervensi keperawatan yang sudah ada di rumah sakit dan perlu dilakukan penelitian lebih lanjut untuk pemilihan terapi musik dengan jumlah sampel yang lebih besar.

\section{Daftar Pustaka}

Djohan. (2009). Psikologi Musik. Yogyakarta: Buku Baik.

Faradisi, F. (2012). Efektivitas Terapi Murotal dan Terapi Musik Klasik Terhadap Penurunan Tingkat Kecemasan Pasien Preoperasi di Pekalongan. Jurnal Ilmiah Kesehatan. Vol. $5(2)$

Guetin, S. (2009). Impact of Music Therapy On Anxiety And Depression For Patients with Alzheimer's Disease and an The Burden Felt By The Main Caregiver (feasibility study). Enchephale journal Vol. 35: 57-65. French.

Hawari, D. (2006). Managemen Stress, Cemas dan Depresi. Jakarta: Fakultas Kedokteran Universitas Indonesia.

Jawaid, M., Musthtaq, A., Mukhtar, S., and Khan, Z . (2007). Preoperative Anxiety before elective surgery. 12(2): 145-148. Neuroscience Journal.

Kaplan, H.I., Sadock, B.J., dan Grebb, J.A. (2010). Sinopsis Psikiatri Psikiatri Ilmu Pengetahuan Perilaku Psikiatri Klinis Jilid 1. Jakarta: Binarupa Aksara.

Lin, Y., Chu H., Yang C. Y., Chen C. H., and Chen H. J. (2011). Effectiveness of group music intervention against agitated behavior in elderly persons with dementia. International Journal of Geriatry Psychiatry Vol. 26: 670-678. UK

Masdin, I. (2010). Pengaruh Terapi Musik Terhadap Perubahan Tingkat Kecemasan pada Pasien Pre Anestesi di Ruang IBS RSUD Wates. Jurnal Keperawatan hal. 1-2. Poltekkes Kemenkes Yogyakarta.

Nurmala. (2009). Keefektivitasan Intervensi Komunikasi Terapeutik Dalam Menurunkan Kecemasan Pasien Pre Anestesi di RSUD Muntilan. Jawa Yogyakarta: Poltekkes Kemenkes Yogyakarta

Pratiwi, N.P.M. (2009). Pengaruh Terapi Musik Klasik Terhadap Tingkat Kecemasan pada Pasien Pre Operasi di RSUP Dr Soeradji Tirtonegoro Klaten. Jurnal Penelitian Keperawatan.

Savitri, W. (2016). Terapi Musik dan Tingkat Kecemasan Pasien Preoperasi. Media Ilmu Kesehatan.Vol. 5(1).

Tamsuri, A. (2007). Konsep dan Penatalaksanaan Nyeri. Jakarta: EGC. 